
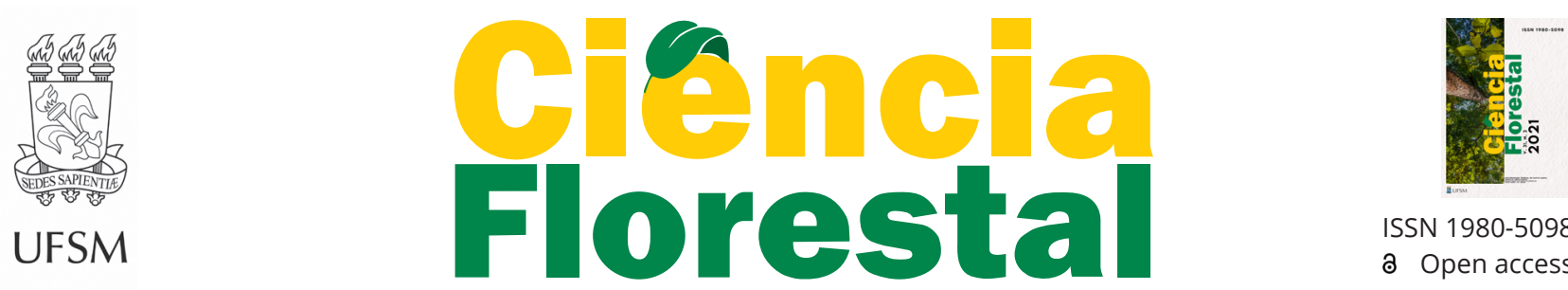

ISSN 1980-5098

a Open access

\title{
Artigos
}

\section{Molecular characterization and vegetative compatibility groups of Fusarium spp. pathogenic to Ilex paraguariensis A. St.-Hil.}

\author{
Caracterização molecular e grupos de compatibilidade vegetativa de \\ Fusarium spp. patogênicos à Ilex paraguariensis A. St.-Hil.
}

\author{
Ricardo Mezzomo ${ }^{\oplus}$ \\ Jéssica Mengue Rolim" $\oplus$ \\ Tales Poletto"II $\odot$ \\ Clair Walkeriv $\odot$ \\ Paola Mendes Milanesi ${ }^{\bullet}$ \\ Marlove Fátima Brião Muniz"II $\odot$
}

'Freelance Researcher, Santa Maria, RS, Brazil

"Universidade Federal de Pelotas, Pelotas, RS, Brazil

"'Universidade Federal de Santa Maria, Santa Maria, RS, Brazil

IVniversidade Estadual de Londrina, Londrina, PR, Brazil

vUniversidade Federal da Fronteira Sul, Erechim, RS, Brazil

\begin{abstract}
In the central-western and southern regions of Brazil, the cultivation of yerba mate (Ilex paraguariensis) is considered an important source of forest extraction, besides providing an alternative income, especially for families. The yerba mate, like other forest species, is infected by several pathogens, such as fungi of the genus Fusarium, causing root rot. Pathogens have wide genetic variability, even within a single genus and species, resulting from adaptations to their environments. This study aimed at characterizing molecularly isolated Fusarium spp. through the sequencing of the ITS and $\beta$-tubulin genome regions, identifying the species level as well as the formation of vegetative compatibility groups (VCG) among these isolates of the root rot pathogen in yerba mate. The sequencing of the ITS and $\beta$-tubulin regions, defined the separation between the seven pathogenic isolates of $F$. solani and $F$. oxysporum. For the same isolates, the technique to obtain nit mutants was suitable for the phenotypic classification, obtaining five VCGs for species of Fusarium, root rot in yerba mate
\end{abstract}

Keywords: ITS; $\beta$-tubulin; nit 


\section{RESUMO}

Nas regiões Centro-Oeste e Sul do Brasil, a cultura da erva-mate (Ilex paraguariensis) constitui-se uma importante fonte de extrativismo florestal, além de diversificar a renda, principalmente na agricultura familiar. A erva-mate, como outras espécies florestais, é infectada por diversos patógenos, como o gênero Fusarium, causador da podridão-de-raízes. Os patógenos possuem ampla variabilidade genética, mesmo dentro de um único gênero e dentro de uma única espécie, resultado de adaptações ao meio em que vivem. Este estudo teve como objetivo avaliar o sequenciamento das regiões do genoma ITS e $\beta$-tubulina na identificação em nível de espécie dos isolados de Fusarium spp. patogênicos à erva-mate, e identificar a formação de grupos de compatibilidade vegetativa (VCG) entre os isolados de Fusarium spp. patogênicos à erva-mate. O sequenciamento das regiões ITS e $\beta$-tubulina consolidou a separação entre os sete isolados patogênicos em $F$. solani e $F$. oxysporum. Para esses isolados, a técnica para obtenção de mutantes nit foi adequada para a classificação fenotípica, fundamentais nos testes de VCG para espécies de Fusarium, sendo obtidos cinco VCG.

Palavras-chave: ITS; $\beta$-tubulina; nit

\section{INTRODUCTION}

The cultivation of yerba mate (Ilex paraguariensis) is an alternative for diversifying the production of small properties mainly in the southern region of Brazil, due to the low initial costs and the ease of using agro-silvopastoral systems, enabling the strengthening of family farming. In Rio Grande do Sul state (RS), southern Brazil, the production chain involves 35 thousand hectares with about 14 thousand properties, in addition to 300 nurseries and 250 herbaceous industries, generating a gross income of approximately R\$1 billion/year (FUNDO DE DESENVOLVIMENTO E INOVAÇÃO DA CADEIA PRODUTIVA DE ERVA-MATE, 2014). However, yerba mate is subject to attack by pathogens, such as fungi of the genus Fusarium, known to cause diseases, such as root rot, that leads to reduced productivity.

Root rot interferes directly with the plant nutrient intake. The symptoms are observed in the shoot, including leaf spots, yellowing, leaf fall, reduction in growth, wilting and dryness and even to the death of the seedling (GRIGOLETTI JUNIOR; AUER; MASCHIO, 1996).

For control and preventive strategies to be implemented, therefore, studies are required to understand the correct identification and genetic variability of the fungus that causes the disease. 
A precise way to identify pathogen variability is the use of molecular techniques, allowing the development of rapid, sensitive, and specific methods in the diagnosis of phytopathogens. In addition, its wide usage is mainly due to its simplicity, speed, safety, and amplitude of the obtained results (TEIXEIRA; VIEIRA; MACHADO, 2004).

However, in some cases, the use of molecular techniques is insufficient to detect intraspecific variability among species of Fusarium. Thus, the identification of vegetative compatibility groups (VCG) is commonly employed in the characterization of diversity among fungal isolates, allowing the distinction between populations (ROSALEE; COELHO; DHINGRA, 1999). In this context, vegetative compatibility is employed as a resource capable of identifying the genetic variability within fungal populations. This technique is based on the anastomosis of hyphae expressing homologous alleles, leading to the formation of stable heterokaryon (GLASS; JACOBSON; SHIU, 2000).

In view of the above, the objective of this study was to characterize molecular isolates of Fusarium spp. through the sequencing of the ITS and $\beta$-tubulin genome regions, identifying them at the species level, as well as in the formation of vegetative compatibility groups (VCG) among the isolates obtained from yerba mate.

\section{MATERIAL AND METHODS}

\subsection{Isolates from Fusarium spp.}

The experiment was conducted at the "Elocy Minussi” Phytopathology Laboratory of the Center of Rural Sciences of the Federal University of Santa Maria, Santa Maria, Rio Grande do Sul state (RS), Brazil. For the molecular characterization and the VCG test, a Fusarium oxysporum (I6AR2) and six other isolates from Fusarium solani (I1AR1, I8AR1, M3AR2, M4, M5AR2 and M7C1) pathogenic to mate, as described by Mezzomo et 
al. (2018), collected in RS state, and deposited in the mycology collections of the same laboratory, where they remain stored in refrigeration in Eppendorff tubes, containing saline solution $0.85 \% \mathrm{NaCl}$ (Table 1).

Table 1 - Areas for the collection of Fusarium spp. isolates pathogenic to yerba mate

\begin{tabular}{lccc}
\hline Isolate & Collection date & Location & Coordinates (GMS) \\
\hline I1AR1 & January 2015 & Ilópolis/RS & $-28^{\circ} 55^{\prime} 42.5^{\prime \prime} \mathrm{S},-52^{\circ} 08^{\prime} 32.6^{\prime \prime} \mathrm{W}$ \\
I6AR2 & January 2015 & Ilópolis/RS & $-28^{\circ} 53^{\prime} 58.1^{\prime \prime} \mathrm{S},-52^{\circ} 04^{\prime} 48.0^{\prime \prime} \mathrm{W}$ \\
I8AR1 & January 2015 & Ilópolis/RS & $-28^{\circ} 55^{\prime} 48.6^{\prime \prime} \mathrm{S},-52^{\circ} 10^{\prime} 40.1^{\prime \prime} \mathrm{W}$ \\
M3AR2 & March 2015 & Machadinho/RS & $-27^{\circ} 32^{\prime} 46.6^{\prime \prime} \mathrm{S},-51^{\circ} 40^{\prime} 47.7^{\prime \prime} \mathrm{W}$ \\
M4 & March 2015 & Machadinho/RS & $-27^{\circ} 32^{\prime} 45.9^{\prime \prime} \mathrm{S},-51^{\circ} 40^{\prime} 48.1^{\prime \prime} \mathrm{W}$ \\
M5AR2 & March 2015 & Machadinho/RS & $-27^{\circ} 32^{\prime} 16.1^{\prime \prime} \mathrm{S},-51^{\circ} 42^{\prime} 32.4^{\prime \prime} \mathrm{W}$ \\
M7C1 & March 2015 & Machadinho/RS & $-27^{\circ} 33^{\prime} 25.0^{\prime \prime} \mathrm{S},-51^{\circ} 40^{\prime} 04.2^{\prime \prime} \mathrm{W}$ \\
\hline
\end{tabular}

Source: Authors (2017)

\subsection{Molecular characterization of pathogenic isolates of Fusarium spp.}

The isolates from Fusarium spp. were submitted to DNA extraction according to the CTAB method described by Doyle and Doyle (1991). The extracted genomic DNA samples were submitted to Chain Polymerase Reaction (PCR) for amplification of the ITS region (Internal Transcribed Spacer) of the rDNA with the primers ITS1 (5 “TTCCGTAGgTGAACCTGCGG 3") and ITS4 (5 "TCCTCCGCTtATtGATATGC 3") (WHITE et al., 1990), as well as the beta-tubulin region ( $\beta$-tubulin) amplified with the pair of Btub-F primers (AAGGGHCAYTAYACYGARGG) and Btub-R (CATGTTGGACTCDGCCTC), developed at the Biological Institute - São Paulo, SP state. The reaction was performed with $30 \mathrm{ng}$ of DNA, $10 \mathrm{X}$ buffer, $2.5 \mu \mathrm{M}$ of each dNTP, $20 \mathrm{nM} \mathrm{MgCl}{ }_{2}, 25$ poles of each of the oligonucleotide primers, five units of the enzyme Taq polymerase and ultrapure water to complete the reaction volume. The reactions were carried out in a thermal cycler MJ Research, INC. PTC - 100MT, under the following thermal conditions: $94^{\circ} \mathrm{C}$ for $2 \mathrm{~min}, 30$ cycles of $94^{\circ} \mathrm{C}$ for $45 \mathrm{~s}, 55^{\circ} \mathrm{C}$ for $30 \mathrm{~s}, 72^{\circ} \mathrm{C}$ for $35 \mathrm{~s}$ and $72^{\circ} \mathrm{C}$ for $10 \mathrm{~min}$. At 
the end of the reaction, the PCR products were maintained at $4^{\circ} \mathrm{C}$. A negative control without DNA was included in PCR amplifications. Amplified fragments and control were separated by $1.2 \%$ agarose gel electrophoresis in 1X TBE buffer (10.8 $\mathrm{g}$ of tris base, 5.5 $\mathrm{g}$ of boric acid, $4 \mathrm{~mL}$ of $0.5 \mathrm{M}$ EDTA and $4 \mathrm{~mL}$ of distilled water), containing ethidium bromide, viewed under ultraviolet light. The PCR products were purified with 13\% PEG 8000 and, in the sequencing reactions, the oligonucleotides ITS1 and ITS4 were used. The sequences generated contained 400 to $900 \mathrm{bp}$, the size related to the segment corresponding to regions ITS1, 5.8S and ITS2 (HALL, 1999).

The sequencing of the genomic regions was performed on a Mega BACE 500 sequencer (Amersham) and the sequenced fragments were analyzed through the BioEdit program (HALL, 1999). The obtained nucleotide sequences were compared with those already existing in GenBank, so that the pathogens isolated and the GenBank sequences that had the highest coverage scores and similarity could be selected and aligned together with the sequences obtained in the ClustalW algorithm sequencing. The phylogenetic analysis was performed using the Neighbor-joining statistical method with 1000 replicates, by the MEGA version 4 program (TAMURA et al., 2007). The model used was chosen according to the available online program, FindModel, which establishes the best model after supplying data showing the chosen sequences aligned through BioEdit, Hall (1999), or another program. The similarity of the nucleotide sequences among the isolates was calculated using the Basic Local Alignment Search Tool - BLAST procedure.

\subsection{Obtaining the nit mutants}

The isolates from Fusarium spp were transferred to Petri dishes containing minimal (MM) medium and incubated in the dark for seven days at $24^{\circ} \mathrm{C}$. The trace element solution was composed of citric acid, $5 \mathrm{~g} \mathrm{ZnSO} \cdot 6 \mathrm{H}_{2} \mathrm{O}, 1 \mathrm{~g} \mathrm{Fe}\left(\mathrm{NH}_{4}\right)_{2} \mathrm{SO}_{4} \cdot 6 \mathrm{H}_{2} \mathrm{O}$,

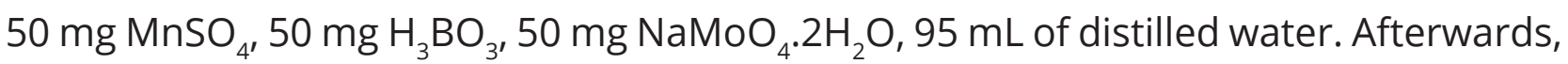


disks of mycelia agar ( $5 \mathrm{~mm}$ ) arranged in a triangular arrangement were transferred to 10 Petri dishes per isolate containing minimal medium plus potassium chlorate (MMC), in the concentration of 1,5, 2 and $2.5 \%$ plus $1,6 \mathrm{~g} / \mathrm{L}$ of $\mathrm{L}$-asparagine for the induction of mutants, which are manifested in sections in the colony. The plates were kept in the dark at $25 \pm 2{ }^{\circ} \mathrm{C}$ for 14 to 21 days (PUHALLA, 1985; CORRELL; PUHALLA; SCHNEIDER, 1986). After the formation of the sectors, a single sector of each mycelial disc was removed and transferred to plates containing minimal ( $\mathrm{MM})$ medium. The isolates that presented thin growth in MM were classified as nit mutants. However, the sectors that presented robust growth were discarded (LESLIE, 1993).

\subsection{Phenotypic characterization of nit mutants}

The nit mutants which showed low growth in MM were transferred to Petri dishes containing culture medium with different nitrogen sources: sodium nitrate (2 g/L); sodium nitrite $(0.5 \mathrm{~g} / \mathrm{L})$ and hypoxanthine $(0.2 \mathrm{~g} / \mathrm{L})$ (PUHALLA, 1985; CORRELL; PUHALLA; SCHNEIDER,1986). After spiking in the different media, the plates were kept in the dark at $25 \pm 2^{\circ} \mathrm{C}$ for a period of 3-4 days (LESLIE; SUMMERELL, 2006). Three classes designate mutant phenotypes nit in the genus Fusarium, which are based on mutation in the nitrogen assimilation route (Table 2) (PUHALLA, 1985; CORRELL; PUHALLA; SCHNEIDER, 1986).

Table 2 - Use of different nitrogen sources in the phenotyping tests

\begin{tabular}{|c|c|c|c|}
\hline Mutant & Nitrate & Nitrite & Hypoxanthine \\
\hline Wild & + & + & + \\
\hline nit1 & - & + & + \\
\hline nit 3 & - & - & + \\
\hline nit $\mathrm{M}$ & - & + & - \\
\hline
\end{tabular}

Source: Authors (2017) 


\subsection{Vegetative compatibility test}

The pairings were performed in MM and allocated in combinations containing the nit mutants 1 in the center of the Petri dish and the M/nit 3 mutants at the ends. In nits of the same species studied the positive control was observed with aerial mycelium growth in the line of intersection between nit 1 and nit $\mathrm{M} / \mathrm{nit} 3$. Among the different isolates, the positive reactions follow as described above; that is, they were observed through aerial mycelium growth in the line of intersection between nit 1 and nit $\mathrm{M} / n$ it 3, confirming the classification of these isolates as belonging to the same VCG. Negative reactions were observed through thin growth in the line of intersection between nit 1 and nit M/nit 3 of different species (PUHALLA, 1985; CORRELL; PUHALLA; SCHNEIDER, 1986; LESLIE; SUMMERELL, 2006).

\section{RESULTS AND DISCUSSION}

In the sequencing of the ITS region (ITS1, 5.8S and ITS2) (Figure 1), the M3AR2 and M4 isolates were allocated in a large clade (branch) together with the sequences of Fusarium solani used in the comparison with bootstrap of 99\%. Isolates I1AR1, I8AR1, as well as M5AR2 and M7C1 were allocated in two distinct clades with bootstrap of 61 and $63 \%$, respectively. However, when compared to the other F. solani, the support of bootstrap increases to $99 \%$ similarity.

Even with bootstrap values (61, 63 and $65 \%$ ), it was observed that the sequencing of the ITS region allowed the separation of the F. solani (M1AR2, M4, M5AR2 and M7C1) assigned to different branches to those collected in llópolis - RS state (I1AR1 and I8AR1). During alignment, the I6AR2 isolate was assigned to a single clado added to the other 10 sequences used, with the support of bootstrap of $99 \%$ similarity, identified as $F$. oxysporum. 
Figure 1 - Phylogenetic dendrogram based on the method Neighbor-joining from DNA sequences of the ITS region. The numbers on the branches indicate the percentage of repetitions of the bootstrap analysis in which the repetitions were observed $(1,000$ repetitions). A sequence of Lasiodiplodia subglobosa was used as outgroup

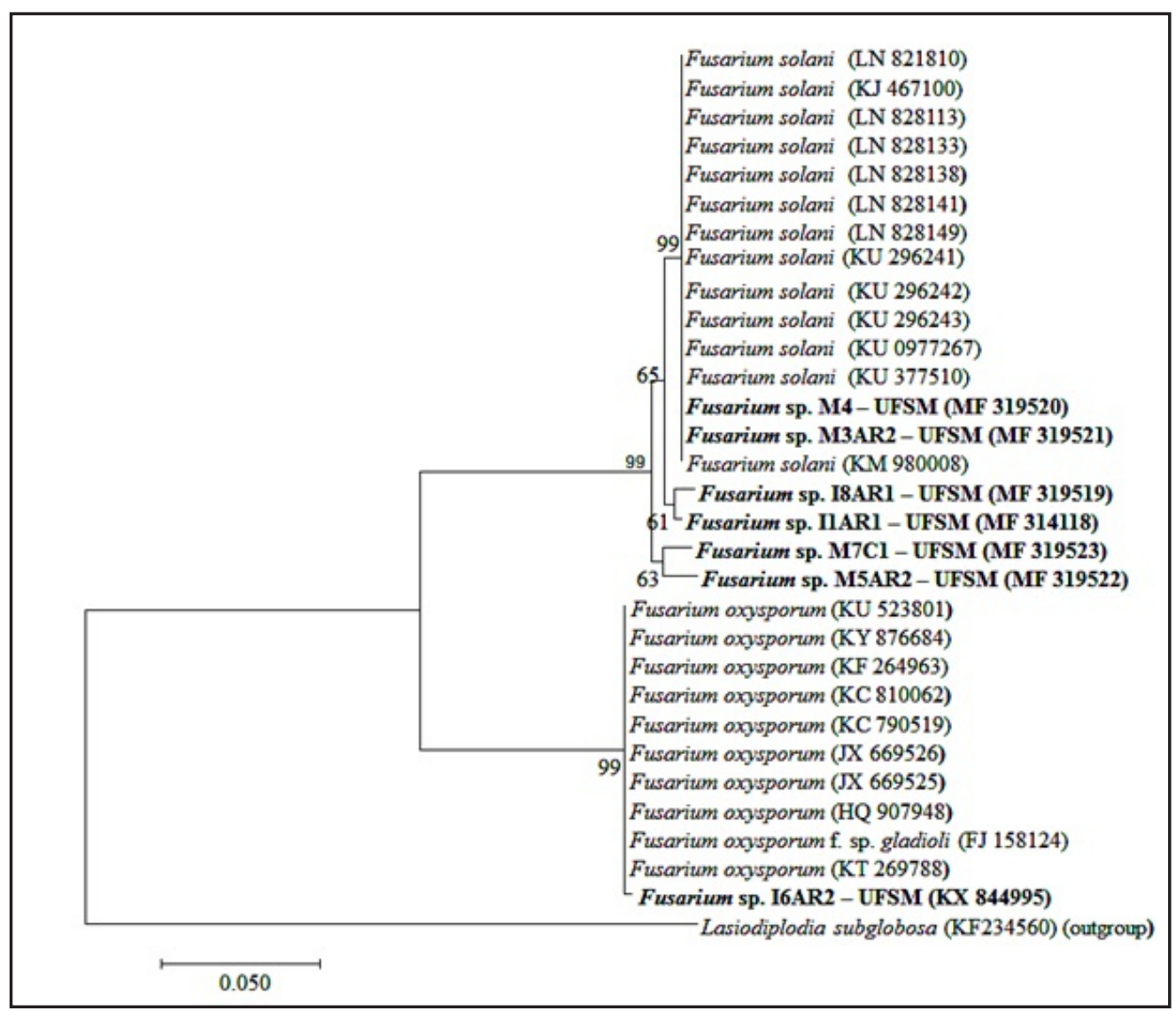

Source: Authors (2017)

Together with the sequencing of the ITS region and the dendrogram resulting from the analysis, it was possible to determine the species in question. Corroborating the results of the present study, the dendrogram obtained by Shahnazi et al. (2012) clearly identifies the formation of two clades, discriminating the species of $F$. solani and F. proliferatum. In addition, this result was supported by a high bootstrap value (100\%). According to Visentin et al. (2009), the sequencing of the ITS region was effective in distinguishing Fusarium verticillioides and Fusarium proliferatum, collected in maize producing regions in northwestern Italy. According to Datta et al. (2011) the use of 
specific primers for the ITS1 and ITS2 regions was effective in distinguishing 12 isolates from Fusarium spp. obtained from different regions of India. However, the authors highlighted a slight presence of polymorphism in the amplified region of rDNA, making it difficult to separate some isolates into three distinct groups. The sequencing of the $\beta$-tubulin region (Figure 2) confirmed and consolidated the identification of $F$. solani (I1AR1, I8AR1, M3AR2, M4, M5AR2, M7C1) and F. oxysporum (IAR2). In both cases, the formation of a single clade per species was verified. Despite the high bootstrap (99\%), this analysis did not provide the intraspecific differentiation of $F$. solani observed in the previous sequencing.

Figure 2 - Phylogenetic dendrogram based on the method Neighbor-joining from $\beta$-tubulin region DNA sequences. The numbers on the branches indicate the percentage of repetitions of the bootstrap analysis in which the repetitions were observed (1000 repetitions). A sequence of Lasiodiplodia subglobosa was used as outgroup

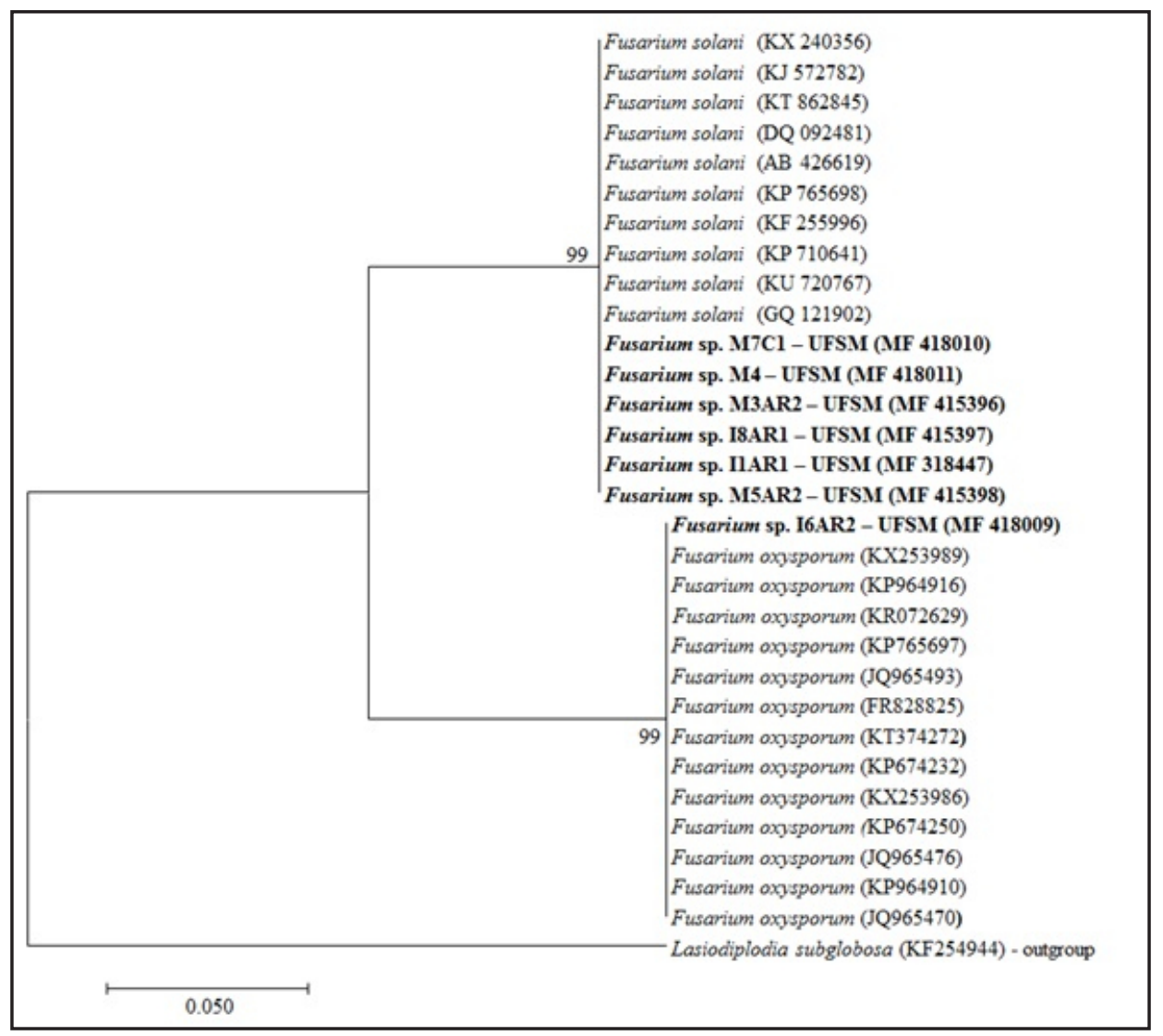

Source: Authors (2017) 
Even with the formation of single clades supported by a high bootstrap, the sequencing of the $\beta$-tubulin region has consolidated the species-level identification of pathogenic Fusarium spp. Jost et al. (2004), emphasize that introns studies are fundamental in species-level identification, since these elements are essential and specific for the expression and regulation of $\beta$-tubulin genes. For Bogale et al. (2009), the $\beta$-tubulin region allowed the separation of Fusarium solani in two distinct clades. According to Jacobs et al. (2010), isolates from F. ananatum and F. guttiforme of pineapple fusariosis were clearly separated into different clades using the $\beta$-tubulin gene region.

Considering from the seven pathogenic isolates Fusarium spp., only I1AR1 and M7C1 did not form resistant sectors when cultured in minimal medium supplemented with mutagenic agent potassium chlorate (MMC). The other isolates had resistant sections and were classified as nit mutants (Figure 3). The isolate from F. oxysporum (I6AR2) was the only one to form more than one sector per block, but not necessarily the most expressive number of sectors, since for the analysis, only one sector was used per block.

Figure 3 - Production of resistant sectors of $\mathrm{KClO}_{3}$ isolates of Fusarium solani. (A): M3AR2 and (B): M5AR2

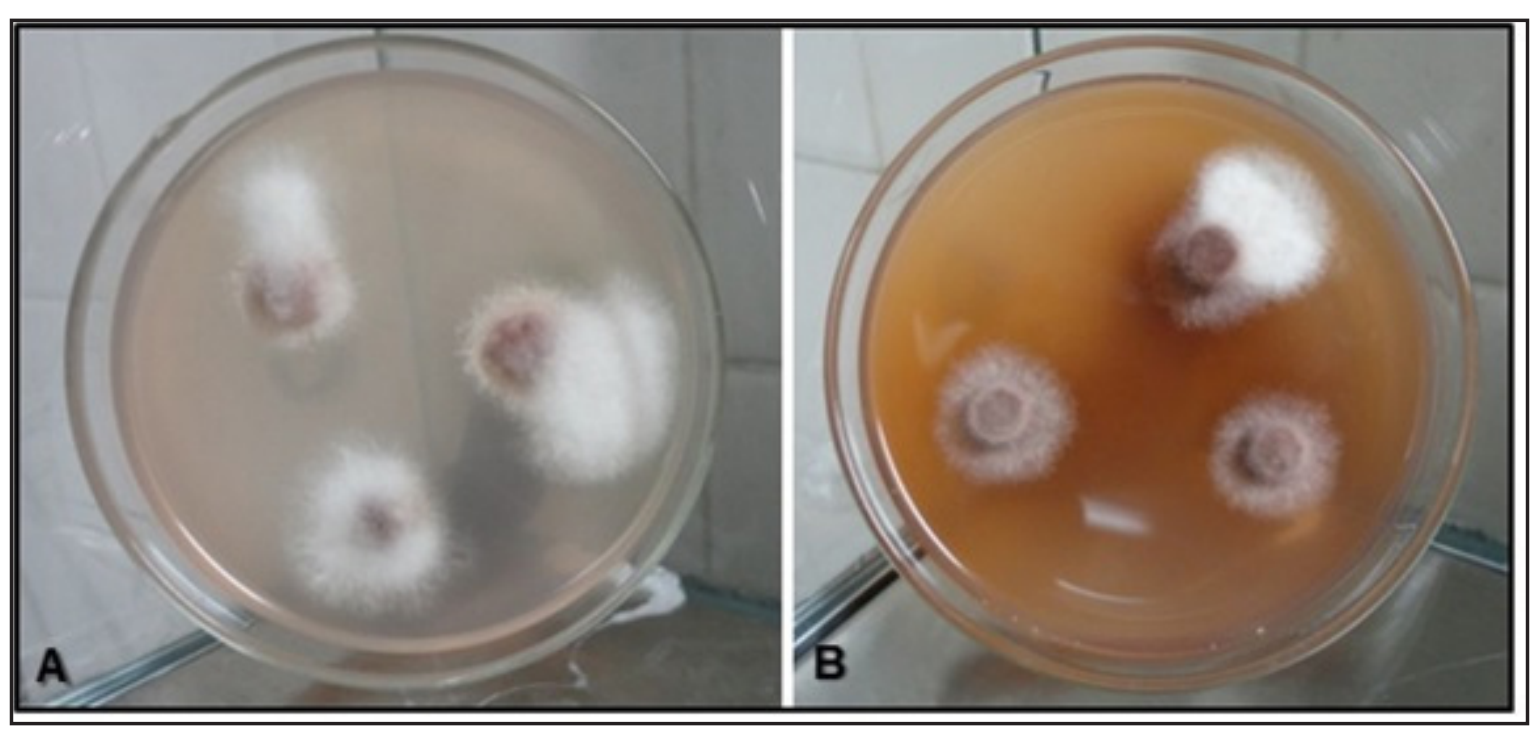

Source: Authors (2017) 
The formation of sectors constitutes the first step for the identification of VCGs. For Saabale and Dubey (2014) the first signs of sectors were confirmed between the second and third week of incubation. In their studies, the authors analyzed 499 sectors resistant to $\mathrm{KClO}_{3}$ from 39 isolates of F. oxysporum f. sp. ciceri, causal agent of chickpea wilt (Cicer arietinum), collected in 13 regions of India. Kiprop et al. (2002) report similar results for the emergence of sectors between the first and second week of culture in MMC of F. udum from pigeon pea (Cajanus cajan) in plantations in Kenya, India and Malawi.

From the total of 38 sectors identified as resistant to potassium chlorate, the highest number was obtained at the concentration of $1.5 \%$. However, the concentration of $2.5 \%$ was responsible for the formation of $20 \%$ of them. The $2 \%$ concentration did not contribute to the mutation of the isolates. Twelve sectors indicated robust growth in $\mathrm{MM}$ and were discarded. There was a difference between the isolates of $F$. solani and $F$. oxysporum in the production of sectors resistant to $\mathrm{KClO}_{3}$, despite the various concentrations used. According to Altinok, Can and Çolak (2013) the concentration of $2 \%$ provided the highest number of mutants generated by $F$. oxysporum $\mathrm{f}$. sp. melongenae eggplant isolates (Solanum melongena). For Alcázar et al. (2006) the addition of $30 \mathrm{~g} / \mathrm{L}$ of potassium chlorate in the MM provided the best composition of the isolate F. oxysporum f. sp. radicis-cucumerinum from cucumber plantations (Cucumis sativus L.) in the province of Almería in Spain. Dias, Abreu and Resende (2014) was successful in restoring sectors using the $50 \mathrm{~g} / \mathrm{L}$ concentration and the mean frequency was 0.50 to 1.40 sectors of $F$. oxysporum f. sp. cubense when grown in MMC.

The growth in $\mathrm{MM}$ containing nitrate $\left(\mathrm{NO}_{3}^{-}\right)$, nitrite $\left(\mathrm{NO}_{2}^{-}\right)$and hypoxanthine $(\mathrm{HP})$ as sources of nitrogen, resulted in 10 nit mutants 1 (38.46\%), 10 nit $\mathrm{M}(38.46 \%)$ and 6 nit mutants3 (23.08\%) (Table 3).

Three groups designate mutant phenotypes that are based on mutations in the nitrate assimilation pathway. Mutations may occur in the structural locus of nitrate reductase (nit 1), in the specific structural locus of the nitrate assimilation 
metabolic pathway (nit 3) or at the locus that affects the pathways of the enzyme co-factor containing molybdenum required for the activity of nitrate reductase and purine dehydrogenase (nit M) (LESLIE, 1993). According to Ilić et al. (2013), the nit 3 phenotype (43\%) prevailed among the 230 mutants recovered from 16 isolates from F. oxysporum collected in four regions of Croatia. Alvarado, Resendes and Fernandez (2012), consolidated the hegemony of nit 1 (36.91\%) of the 149 nit restored from 15 isolates of F. mexicanum, cause of hose malformation (Mangifera indica), in Jalisco, Mexico. According to the authors, the percentages of phenotypes nit Mine nit 3 were 28.18 and $19.46 \%$, respectively, differing from the results of the present study, in which the nit 3 had the lowest percentage among the identified phenotypes.

Table 3 - Phenotypic classification of nit mutants obtained from Fusarium spp. pathogenic to yerba mate

\begin{tabular}{|c|c|c|c|c|}
\hline \multirow{2}{*}{ Isolate } & \multicolumn{3}{|c|}{ Phenotype of mutants nit } & \multirow{2}{*}{$\mathrm{N}^{\circ}$. mutants nit } \\
\hline & nit 1 & nit 3 & nit $\mathrm{M}$ & \\
\hline I6AR2 & 1 & - & 4 & 5 \\
\hline I8AR1 & 2 & 1 & 2 & 5 \\
\hline M3AR2 & 3 & - & 1 & 4 \\
\hline M4 & 1 & 3 & - & 4 \\
\hline M5AR2 & 3 & 2 & 3 & 8 \\
\hline №. phenotypes & 10 & 6 & 10 & 26 \\
\hline
\end{tabular}

Source: Authors (2017)

In the self-compatibility test the nit mutants were found to be compatible in all isolates; that is, they formed stable heterocyclic (Figure 4).

According to the results obtained in the complementation test, the different isolates were allocated to five different VCGs. Each VCG was composed of one isolate. The distribution of the isolates in different VCGs suggests the existence of genetic variability, mainly among the isolates of $F$. solani, as pointed out in the sequencing of the ITS region. 
According to Leslie (1993), mutants that do not form a stable heterocyan are classified as self-incompatible and cannot be used for the determination of VCGs. Reinforcing the results of the present study, Jusoh, Zin and Nagao (2013) obtained 12 VCGs composed of only one isolate, from the pairing of 12 isolates of $F$. solani (5 pathogenic and 7 non-pathogenic) obtained from tobacco (Nicotiana tabacum L.) in five producing regions in the eastern coast of Malaysia. The authors attributed the sexual reproduction to the degree of genetic diversity of the isolates. Similar results were reported by Crespo (2010) where isolates from the same region were classified in different VCGs, supporting local variability. Still, according to the author, the presence of isolates from different regions in the same VCG would indicate the spread of the pathogen from one region to another. According to Elena and Pappas (2002) of the 23 isolates of F. oxysporium f. sp. phaseoli obtained in different regions of Greece, six were classified as single VCGs. According to these authors, the presence of 15 isolates in the same VCG may be related to the genetic homogeneity present in the population of $F$. oxysporumf.sp. phaseoli studied. Puhalla (1985) states that isolates belonging to the same VCG are genetically similar, which reinforces the hypothesis of the existence of genotypic variability among the isolates used in the present study.

Figure 4 - Test of compatibility in minimal medium (MM). (A) and (B): self-compatibility of isolates M4 and I8AR1, respectively; (C): pairing between I6AR2 and I8AR1 isolates

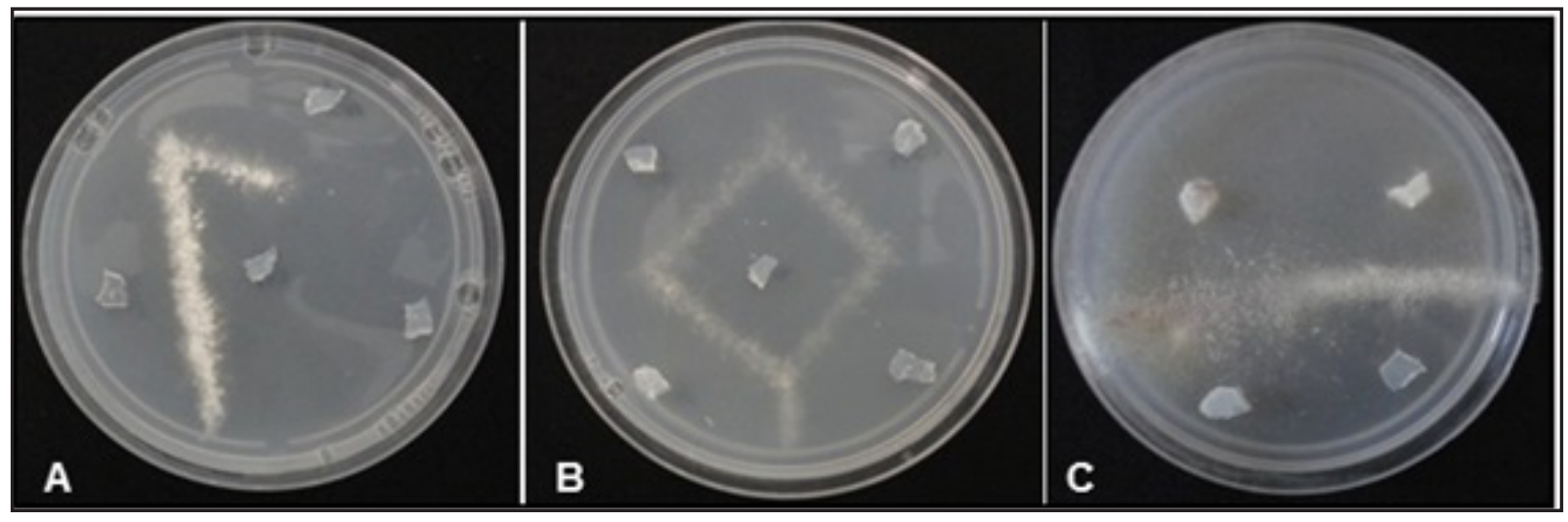

Source: Authors (2017) 


\section{CONCLUSION}

The regions ITS and $\beta$-tubulin when used together are efficient and give greater reliability in the identification at the level of species within the genus Fusarium. The results suggest the existence of genetic variability among populations, but they point out the need for additional studies on the number and distribution of VCGs present in the patho system Fusarium $\times$ yerba mate.

\section{ACKNOWLEDGEMENTS}

The authors thank the Coordination for the Improvement of Higher Education Personnel (CAPES) for the granting of a PhD grant to the first author and CNPq of the Research Productivity Grant of the co-author Marlove Fatima Brião Muniz.

\section{REFERENCES}

ALCÁZAR, M. G. et al. Grupos de compatibilidad vegetativa de Fusarium oxysporum f. sp. radiciscucumerinum em la Provincia de Alméria. Boletín de Sanidad Vegetal Plagas, Madrid, v. 32, n. 1, p. 535-543, 2006.

ALTINOK, H. H.; CAN, C.; ÇOLAK, H. Vegetative Compatibility, Pathogenicity and Virulence Diversity of Fusarium oxysporum f. sp. melongenae Recovered from Eggplant. Journal Phytopathology, Berlin, v. 161, n. 9, p. 651-660, 2013.

ALVARADO, G. H.; RESENDES, I. B.; FERNÁNDEZ, R. R. Caracterización de Grupos de Compatibilidad Vegetativa de Fusarium mexicanum Causante de la Malformación del Mango en Jalisco, México. Revista Mexicana de Fitopatología, Texcoco, v. 30, n. 2, p. 128-140, 2012.

BOGALE, M. et al. Diverse Fusarium solani isolates colonise agricultural environments in Ethiopia. European Journal of Plant Pathology, Dordrecht, v. 124, n. 3, p. 369-378, 2009.

CORRELL, J. C.; PUHALLA, J. E.; SCHNEIDER, R. W. Identification of Fusarium oxysporum f. sp. apiion the basis of colony size, virulence, and vegetative compatibility. Phytopathology, St. Paul, v. 76, n. 4, p. 396-400, 1986.

CRESPO, N. C. Diversidade genética de isolados do agente etiológico da fusariose do abacaxizeiro no Brasil. 2010. (Mestrado em Agronomia) - Universidade Federal de Lavras, Lavras, 2010.

DATTA, S. et al. Polymorphism in the internal transcribed spacer (ITS) region of the ribosomal DNA among different Fusarium species. Archives of Phytopathology and Plant Protection, [s. I.], v. 44, n. 6, p. 558-566, 2011. 
DIAS, J. S. A.; ABREU, M. S.; RESENDE, M. L. V. Caracterização de isolados de Fusarium oxysporum f. sp. cubense (Foc) quanto à compatibilidade vegetativa e à patogenicidade em cultivares de bananeira diferenciadoras de raças no Brasil. Biota Amazônia, Macapá, v. 4, n. 4, p. 60-65, 2014.

DOYLE, J. J.; DOYLE, J. L. Isolation of plant DNA from fresh tissue. Focus, [s. I.], v. 12, n. 1, p. 13$15,1991$.

ELENA, K.; PAPPAS, A. C. Pathogenicity and Vegetative Compatibility of Fusarium oxysporum f. sp. phaseoli in Greece. Journal Phytopathology, Berlin, v. 150, n. 8-9, p. 495-499, 2002.

FUNDO DE DESENVOLVIMENTO E INOVAÇÃO DA CADEIA PRODUTIVA DE ERVA-MATE. Guia da erva-mate. Porto Alegre, 2014. 15 p.

GLASS, N. L.; JACOBSON, D. J.; SHIU, P. K. The genetics of hyphal fusion and vegetative incompatibility in filamentous ascomycetes. Annual Review of Genetics, Palo Alto, v. 34, p. 165-186, 2000.

GRIGOLETTI JUNIOR, A.; AUER, C. G.; MASCHIO, L. M. A. Doenças em Erva mate (Ilex paraguariensisA. St.-Hill) na região sul do Brasil. Boletim de Pesquisa Florestal, Colombo, v. 32/33, p. 43-51, 1996.

HALL, T. A. BioEdit: a user-friendly biological sequence alignment editor and analysis program for Windows 95/98/NT. Nucleic Acids Symposium, Oxford, v. 41, p. 95-98, 1999.

JACOBS, A. et al. Fusarium ananatum sp. nov. in the Gibberella fujikuroi species complex from pineapples with fruit rot in South Africa. Fungal Biology, Oxford, v. 114, n. 7, p. 515-527, 2010.

ILIĆ, J. et al. Vegetative compatibility of Fusarium oxysporum isolated from weeds in eastern Croatia. Poljoprivreda, Osijek, v. 19, n. 1, p. 20-24, 2013.

JOST, W. et al. A large plant $\beta$-tubulin family with minimal C-terminal variation but differences in expression. Gene, [s. I.], v. 340, n. 1, p. 151-160, 2004.

JUSOH, M. N. B.; ZIN, N. B. M.; NAGAO, H. Vegetative compatibility group of Fusarium solani pathogenic to tobacco plant in peninsular Malaysia. Songklanakarin Journal of Science and Technology, Hat Yai, v. 35, n. 6, p. 615-621, 2013.

KIPROP, E. K. et al. Cultural characteristics, pathogenicity and vegetative compatibility of Fusarium udum isolates from pigeonpea (Cajanuscajan (L.) Millsp.) in Kenya. European Journal of Plant Pathology, Dordrecht, v. 108, n. 2, p. 147-154, 2002.

LESLIE, J. F. Fungal vegetative compatibility. Annual Review of Phytopathology, Palo Alto, v. 31, p. 127-150, 1993.

LESLIE, J. F.; SUMMERELL, B. A. The fusarium laboratory manual. Ames: Blackwell Publishing, 2006. 388 p.

MEZZOMO, R. et al. Morphological and molecular characterization of Fusarium spp. pathogenic to Ilex Paraguariensis. Cerne, Lavras, v. 24, n. 3, p. 209-218, 2018. 
PUHALLA, J. E. Classification of strains of Fusarium oxysporum on the bases of vegetative compatibility. Canadian Journal of Botany, Ottawa, v. 63, n. 2, v. 179-183, 1985.

ROSALEE, A.; COELHO, N.; DHINGRA, O. D. Grupos de compatibilidade vegetativa entre insolados de Fusarium oxysporum não patogênicos ao feijoeiro e de F. oxysporum f. sp. phaseoli. Fitopatologia Brasileira, Brasília, v. 24, n. 4, p. 546-548, 1999.

SAABALE, P. R.; DUBEY, S. C. Pathogenicity and vegetative compatibility grouping among Indian populations of Fusarium oxysporum f. sp. ciceris causing chickpea wilt. Phytoparasitica, Bet Dagan, v. 42, n. 11-12, p. 465-473, 2014.

SHAHNAZI, S. et al. Morphological and molecular characterization of Fusarium spp. associated with yellowing disease of black pepper (Piper nigrum L.) in Malaysia. Journal of General Plant Pathology, [s. I.], v. 78, n. 3, p. 160-169, 2012.

TAMURA, K. et al. MEGA4: Molecular Evolutionary Genetics Analysis (MEGA) software version 4.0. Molecular Biology and Evolution, Oxford, v. 24, n. 8, p. 1596-1599, 2007.

TEIXEIRA, H.; VIEIRA, M. G. G. C.; MACHADO, J. C. Marcadores morfofisiológicos e isoenzimáticos na análise da diversidade genética de isolados de Acremonium strictum. Fitopatologia Brasileira, Brasília, v. 29, n. 4, p. 413-418, 2004.

VISENTIN, I. et al. The ITS region as a taxonomic discriminator between Fusarium verticillioides and Fusarium proliferatum. Mycological Research, London, v. 113, n. 10, p. 1137-1145, 2009.

WHITE, T. J. et al. Amplification and direct sequencing of fungal ribosomal RNA genes for phylogenetics. In: INNIS, M. A. et al. Comparative evolutionary analysis of rDNA ITS regions in Drosophila. Molecular Biology and Evolution, Oxford, v. 11, n. 3, p. 513- 522, 1990.

\section{Authorship Contribution}

\section{1 - Ricardo Mezzomo}

Forestry Engineer, Work Safety Engineer, Dr., Freelance Researcher https://orcid.org/0000-0002-7392-9588•mezzomoricardo@hotmail.com

Contribution: Conceptualization, Data curation, Formal Analysis, Funding acquisition, Investigation, Methodology, Project administration, Resources, Software, Supervision, Validation, Visualization, Writing - original draft, Writing - review \& editing 


\section{2 - Jéssica Mengue Rolim}

Forestry Engineer, MSc.

https://orcid.org/0000-0003-2737-7599•eng.jessicarolim@gmail.com

Contribution: Data curation, Formal Analysis, Investigation, Methodology, Project administration, Software, Validation, Visualization, Writing - review \& editing

\section{3 - Tales Poletto}

Forestry Engineer, MSc.

https://orcid.org/0000-0002-6162-4445•tecnicotales@hotmail.com

Contribution: Data curation, Formal Analysis, Visualization, Writing - original draft, Writing - review \& editing

\section{4 - Clair Walker}

Forestry Engineer, Dr., Professor

https://orcid.org/0000-0002-6707-3963•clairwalker@gmail.com

Contribution: Methodology, Software, Supervision, Validation, Writing - original draft, Writing - review \& editing

\section{5 - Paola Mendes Milanesi}

Agronomist, Dr., Professor

https://orcid.org/0000-0001-7319-916X•paola.milanesi@uffs.edu.br

Contribution: Formal Analysis, Methodology Software, Validation, Visualization, Writing - review \& editing

\section{6 - Marlove Fátima Brião Muniz}

Agronomist, Dr., Professor

https://orcid.org/0000-0001-7436-9589•marlovemuniz@yahoo.com.br

Contribution: Conceptualization, Supervision, Validation, Visualization, Writing - review \& editing

\section{How to quote this article}

Mezzomo, R.; Rolim, J. M.; Poletto, T.; Walker, C.; Milanesi, P. M.; Muniz, M. F. B. Molecular characterization and vegetative compatibility groups of Fusarium spp. pathogenic to Ilex paraguariensis A. St.-Hil. Ciência Florestal, Santa Maria, v. 31, n. 2, p. 846-862, 2021. DOI 10.5902/1980509846843. Available from: https://doi.org/10.5902/1980509846843. Accessed: xx abbreviated-month 2021. 